\title{
Contrasting patterns of phytoplankton viability in the subtropical NE Atlantic Ocean
}

\author{
Patricia Alonso-Laita*, Susana Agustí \\ Institut Mediterrani d'Estudis Avançats IMEDEA (CSIC-UIB), Miquel Marqués, 21, 07190 Esporles, Mallorca, Spain
}

\begin{abstract}
The proportion of living phytoplankton cells (\% LC) was quantified in natural communities along 2 transects of the subtropical NE Atlantic. The region is characterized by the dominance of nano- and micro-phytoplankton in the coastal NW African upwelling zone and picophytoplankton in the oligotrophic open ocean. Among the pico-cyanobacteria, Synechococcus sp. $\%$ LC (40 to $100 \%$ LC) was generally higher than that observed for Prochlorococcus sp. (20 to $90 \%$ LC). The \% LC values of both Prochlorococcus sp. and Synechococcus sp. were low at the oligotrophic open ocean stations and decreased towards the coastal upwelling area. Both Prochlorococcus sp. and Synechococcus sp. \% LC increased in waters in which temperatures reached $>21^{\circ} \mathrm{C}$. The vertical variability of Prochlorococcus sp. \% LC was related to the underwater visible and ultraviolet radiation, showing lower viability in the surface waters. The \% LC of nano- and micro-phytoplankton varied with the trophic conditions of the waters, showing lowest values $(18.6$ and $11.8 \%$ LC, respectively) in the oligotrophic open ocean and highest values (98.9 and $80.0 \%$ LC, respectively) in the coastal upwelling area. However, both nano- and micro-phytoplankton viability decreased as the water temperature increased. This pattern contrasted strongly with that found for pico-cyanobacteria, indicating that the factors stressing the pico-sized and larger phytoplankton cells in the region were different. As a result of the \% LC distribution of the different phytoplankton communities, the highest level of phytoplankton cell death was found in the oligotrophic area, while larger proportions of healthy, living cells were generally found in communities in the upwelling zone. The results identified cell death as an important factor structuring phytoplankton communities in the ocean.
\end{abstract}

KEY WORDS: Subtropical NE Atlantic $\cdot$ Phytoplankton communities $\cdot$ Cell death $\cdot$ Synechococcus Prochlorococcus $\cdot$ Nano-phytoplankton $\cdot$ Micro-phytoplankton $\cdot$ Stressing conditions

\section{INTRODUCTION}

The subtropical NE Atlantic is characterized by a sharp gradient in nutrient conditions, from the nutrient-rich upwelling on the NW African coast (Van Camp et al. 1991) to the oligotrophic waters of the North Atlantic Subtropical Gyre. This gradient generates a gradient in plankton productivity, from high production rates in the upwelling area to the low productivity of the subtropical gyre waters (e.g. Hoepffner et al. 1992, Longhurst 1996). The increased phytoplankton biomass and production in the upwelling areas is associated with the development of a phytoplankton community composed of large cells, generally dominated by diatoms (Estrada \& Blasco 1985, Lange et al.
1998). In contrast, the oligotrophic waters of the North Atlantic Subtropical Gyre show phytoplankton communities dominated by pico-phytoplankton cells (Olson et al. 1990, Partensky et al. 1996, Zubkov et al. 1998, Agustí et al. 2001). Phytoplanktonic loss processes, such as phytoplankton cell lysis rates, also vary along this gradient in the subtropical NE Atlantic, with higher specific rates found in the oligotrophic waters than in the upwelling zone (Agustí et al. 2001), suggesting changes in the level of stress experienced by phytoplankton. Changes in the composition of the phytoplankton communities in the subtropical NE Atlantic should be a combined result of varying growth capacities and sensitivities to stress of the phytoplanktonic groups forming the communities in response to 
the varying environmental conditions. However, analyses of phytoplankton communities have traditionally emphasized the roles of competitive capacity and resource use as the main structuring processes (e.g. Grover 1990, Huisman \& Weissing 1995) and have largely neglected the potential roles of losses and differential sensitivities to stress. Yet, recent analyses have suggested differential mortality across taxa to be a major factor structuring phytoplankton communities in the Mediterranean littoral community (Agustí \& Sánchez 2002) and Atlantic Ocean (Veldhuis et al. 2001, Agustí 2004). Whether the strong environmental gradients along the subtropical NE Atlantic generate differences in cell death across the groups forming the phytoplanktonic communities, thereby influencing community structure, remains untested.

The goal of this study was to quantify phytoplankton cell death in the natural communities of the subtropical NE Atlantic across the gradient of environmental conditions and phytoplankton community composition present in this area. We did so by quantifying phytoplankton community composition and the proportion of living cells in the populations of the different groups forming the communities along transects extending from the oligotrophic gyre to the nutrient-rich coastal upwelling regions. Living cells were quantified by using the cell digestion assay (Agustí \& Sánchez 2002), a membrane-permeability test that removes dead cells (which show increased membrane permeability) from the sample, thereby allowing the unambiguous identification of living cells in natural communities. The spatial and vertical variability in the percentage of living cells (\% LC) was analyzed to search for patterns in the distribution of phytoplankton cell death and to analyze the different sensitivities to stress conditions of the different phytoplanktonic groups forming the communities.

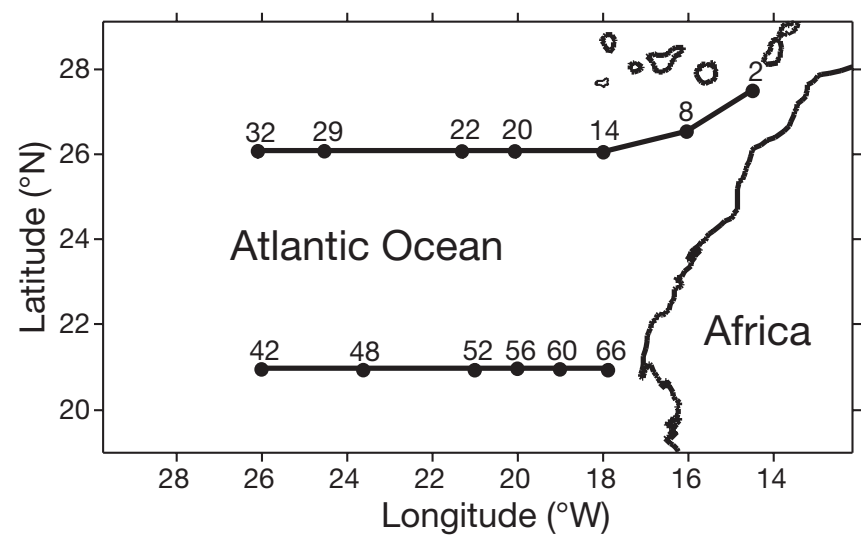

Fig. 1. Study area, transects and stations sampled during the cruise COCA-2 (May to June 2003). Numbers correspond to station numbers

\section{MATERIALS AND METHODS}

The observations reported were carried out during the oceanographic cruise COCA-2 (19 May to 14 June 2003) on board the RV 'Hespérides'. The area studied encompassed the transition zone between the northeast coastal upwelling area off Africa and the oceanic waters of the North Atlantic at $26^{\circ} \mathrm{W} ; 13$ stations distributed along 2 transects extending from the African coast to the open ocean (Fig. 1) were studied.

Water samples were collected by using 121 Niskin bottles attached to a CTD-rosette system. Samples for the quantification of abundance and viability of picophytoplankton cells $(<2 \mu \mathrm{m}$ diameter $)$ were collected at 12 to 15 depths from the surface $(5 \mathrm{~m})$ to a maximum of $200 \mathrm{~m}$ depth at the 13 stations. Water samples from the surface and the depth of the deep chlorophyll $a$ maximum (DCM) were also collected for the quantification of cell viability and abundance of larger $(>2 \mu \mathrm{m}$ cell diameter) phytoplankton cells (nano- and microphytoplankton). Underwater light was measured at the different stations by using a profiler radiometer (PUVR 2500-Biospherical) fitted with sensors for the simultaneous measurement of pressure, photosynthetically active radiation (PAR) and ultraviolet radiation (UVR).

The proportions of living and dead cells in the populations forming the phytoplankton communities were quantified using the cell digestion assay (Agustí \& Sánchez 2002). The cell digestion assay is a cellmembrane-permeability test based on the brief exposure of the cells tested to the enzymes trypsin and DNAse I. These enzymes enter the cytoplasm of cells with damaged plasma membranes (dead cells), which are then digested by the enzymes and disappear from the sample, while the enzymes have no effect on living cells, which remain in the sample after the assay (Agustí \& Sánchez 2002).

To quantify the abundance and viability of picophytoplankton, the cell digestion assay was applied to duplicate samples from each depth, by adding $100 \mu \mathrm{l}$ of DNAse I solution (400 $\mu \mathrm{g} \mathrm{ml}^{-1}$ in Hank's balanced salt solution, HBSS) to $0.5 \mathrm{ml}$ water sample, followed by incubation for $15 \mathrm{~min}$ at $37^{\circ} \mathrm{C}$. After this time, $100 \mu \mathrm{l}$ of trypsin solution (1\% in HBSS) was added, followed by incubation for an additional $30 \mathrm{~min}$ at $37^{\circ} \mathrm{C}$. At the end of the incubation, samples were placed in ice to stop the reaction and analyzed by flow cytometry. Parallel to this analysis, fresh duplicate samples from each depth were analyzed by flow cytometry to quantify the total abundance of pico-phytoplankton cells.

Samples for the determination of pico-phytoplankton total cell abundance (untreated samples) and living cells (after the cell digestion assay) were counted in duplicate with a FACSCalibur flow cytometer (Beckton Dickinson) fitted with a $488 \mathrm{~nm}$ laser. An aliquot of a 
calibrated solution of $1 \mu \mathrm{m}$ diameter high-green fluorescent beads (Polysciences) was added to the samples as an internal standard for the quantification of cell concentration. The red, green and orange fluorescent emissions and the forward and side scattering (SSC) of the cells and beads were used to detect different populations and to differentiate them from the fluorescent beads (Marie et al. 1999). The Synechococcus population is discriminated from other phytoplankters by its orange fluorescence (due to the presence of phycoerythrin) in the orange (FL2) versus red fluorescence (FL3). Prochlorococcus cells, which are the smallest and least fluorescent, are distinguished from pico-eukaryotes through the bivariate distribution of the SSC (as a function of size) versus red fluorescence (FL3) (Marie et al. 1999). Analysis of fresh samples that yielded sufficient red fluorescence signals from surface Prochlorococcus sp. cells allowed their unambiguous detection by flow cytometry after and before the digestion assay (Fig. 2).

For quantification of the abundance and viability of larger phytoplankton cells (nano- and micro-phytoplankton $>2 \mu \mathrm{m}$ cell diameter), a variable volume of water (between 0.7 and 2 l) was concentrated to a variable volume of 40 to $80 \mathrm{ml}$ by using a Millipore cell concentrator fitted with a $2 \mu \mathrm{m}$ pore diameter filter. The cell digestion method was applied to duplicate 10 to $12 \mathrm{ml}$ subsamples from the cell concentrate by adding 2 to $2.4 \mathrm{ml}$ of DNAse I solution (400 $\mathrm{\mu g} \mathrm{m}^{-1}$ in HBSS) to each sample, followed by incubation for $15 \mathrm{~min}$ at $37^{\circ} \mathrm{C}$. After this time, 2 to $2.4 \mathrm{ml}$ of trypsin solution (1\% in HBSS) was added, followed by incubation for an additional $30 \mathrm{~min}$ at $37^{\circ} \mathrm{C}$. Additional duplicate 10 to $12 \mathrm{ml}$ subsamples from the concentrate were incubated, without enzyme additions, during the same time to quantify the concentration of total cells in the larger (nano- and micro-phytoplankton $>2 \mu \mathrm{m}$ ) fraction. After incubation, the samples were filtered onto $0.6 \mu \mathrm{m}$ pore size black Nucleopore filters, washed several times with filtered seawater to remove the enzymes, fixed with glutaraldehide ( $1 \%$ final concentration) and kept frozen until examined under an epifluorescence microscope (Zeiss Axioplan 2 Imaging) fitted with a blue light filter. The phytoplanktonic cells counted under epifluorescence microscopy were differentiated into nano-plankton, for the cells showing a cell diameter between 2 and $10 \mu \mathrm{m}$, and micro-plankton, including the cells with a $>10 \mu \mathrm{m}$ cell diameter. The micro-planktonic cells were also differentiated into major taxonomic groups (e.g. dinoflagellates and diatoms). A variable number of fields selected randomly were observed until $>100$ cells had been counted.

The cells counted after the cell digestion assay represented the living cells in the community, whereas the cells counted in untreated samples represented the to- tal population (living and dying cells). The percentage of living (or viable) cells was calculated by dividing the concentration of cells after enzyme digestion by the cell concentration of untreated samples, which represented the total (dead plus living) cell population. The number of dead cells was calculated as the difference between the total cell abundance and that of living cells.

The effects of incubation temperature in the viability of pico-planktonic cells were tested on different occasions throughout the cruise by quantifying the abundance in fresh samples and in samples incubated at the assay temperature of $37^{\circ} \mathrm{C}$ for the standard incubation time of $45 \mathrm{~min}$. We found no significant differences (Friedman test, $\mathrm{p}>0.22$, for 8 tests performed) between the cell abundance in fresh untreated samples and
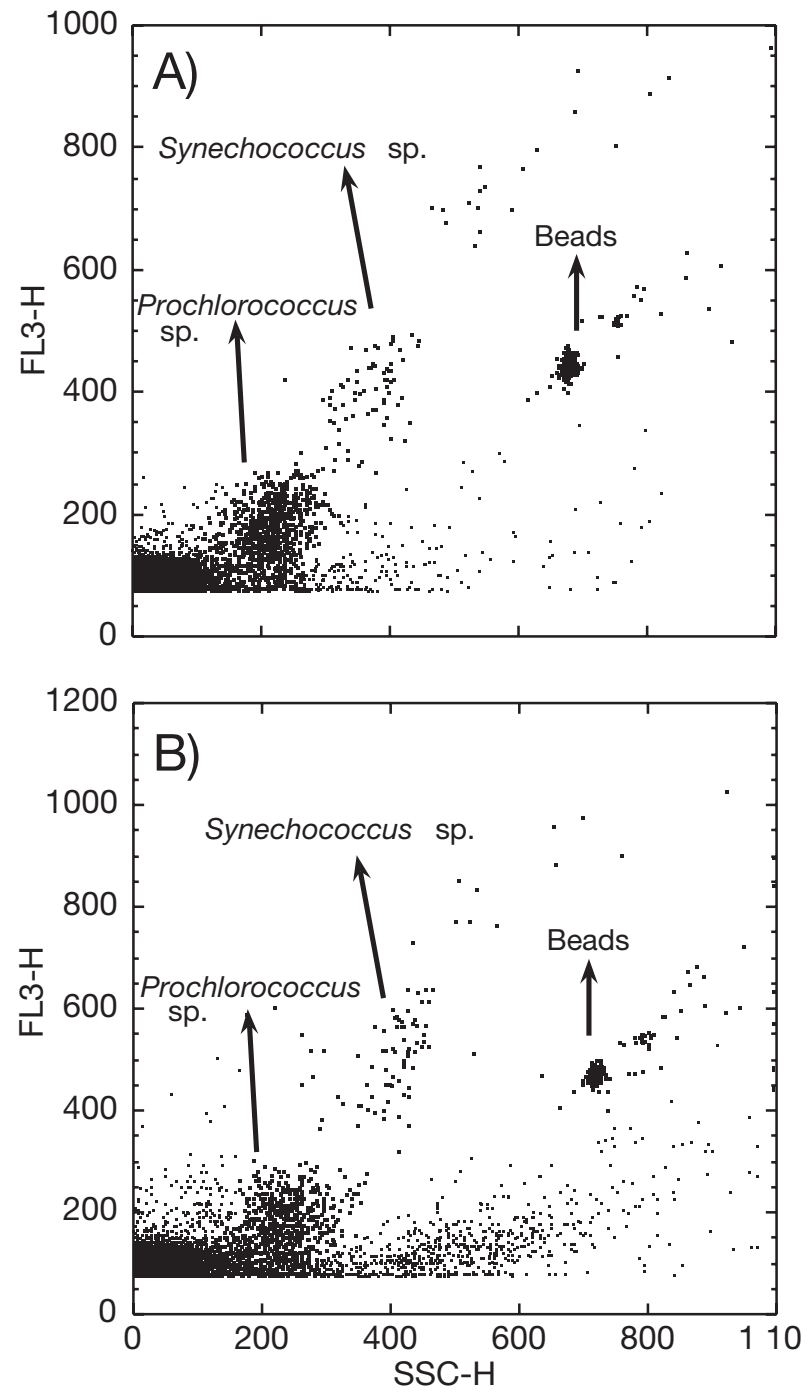

Fig. 2. Flow cytometer signals from low-abundance surface (5 m) samples at Stn 14, obtained in (A) blank samples and (B) after the enzymatic digestion assay. Axes are expressed in arbitrary units and represent red fluorescence (FL3-H) and side scattering $(\mathrm{SSC}-\mathrm{H})$ 
those in samples incubated at $37^{\circ} \mathrm{C}$ for the populations of Prochlorococcus sp., Synechococcus sp. and phytoeukaryotes, indicating that the assay temperature had no measurable effect on the cell concentration. The enzymatic cell digestion method yielded comparable results to those obtained using other cell-membranepermeability tests for pico-phytoplankton (Agustí 2004), as well as for eukaryotic phytoplankton (Agustí \& Sánchez 2002), indicating that despite the incubation performed at $37^{\circ} \mathrm{C}$, there were no differences with the results obtained by using non-incubating methodologies. In spite of the successful application of the method to a wide diversity of species, further testing of a larger number of species should be made to examine the universality of the method.

The average percentage of living cells at each station was calculated, for each phytoplankton group, by averaging the data from the different depths sampled. These data included between 12 to 15 depths sampled for pico-phytoplankton and 2 depths, comprising the surface $(5 \mathrm{~m})$ and the depth of the DCM, for nano- and micro-phytoplankton.
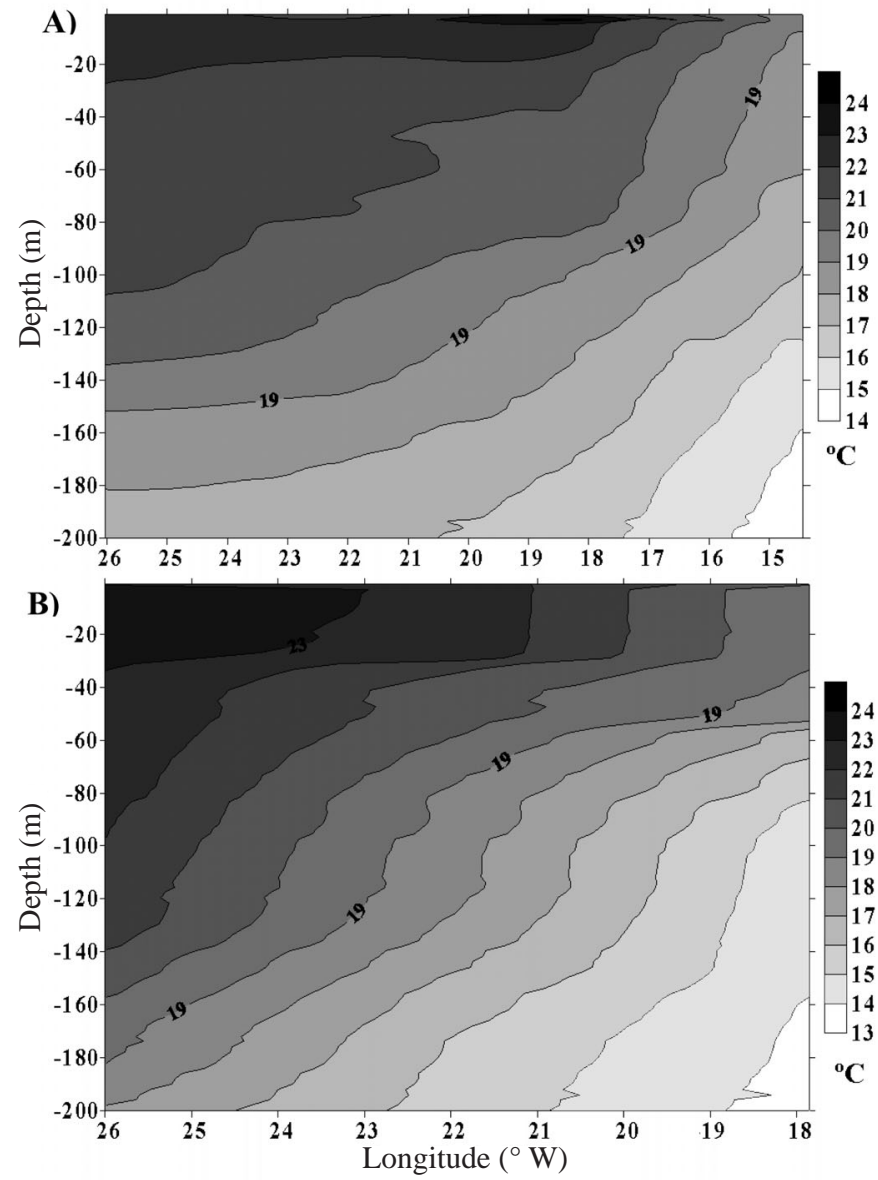

Fig. 3. Distribution of water temperature $\left({ }^{\circ} \mathrm{C}\right)$ found in the (A) northern and (B) southern transects, respectively

\section{RESULTS}

\section{Nutrients}

Examination of the isotherms along the transects clearly showed the influence of coastal upwelling, particularly on the southern transect (Fig. 3). The mixed layer deepened toward the open ocean in both transects, where surface temperature reached higher values in the southern transect and the strongest influence of upwelling was noted in deeper waters (Fig. 3). Nutrient concentrations ranged broadly across the area. In the southern transect, upwelling reached the surface waters; the nutrient concentrations at Stns 60 and 66 were very high, even at the surface $(5 \mathrm{~m})$, where high values of 6.66 and $1.09 \mu \mathrm{M}$ nitrate and 0.3 and $0.25 \mu \mathrm{M}$ phosphate, respectively, were observed. As indicated by the distribution of water masses, described by the variability in water temperature (Fig. 3), at the most oceanic stations of the southern transect, the nutrient concentration decreased, with low values of nutrients found throughout the water column and with nitrate concentrations showing values around $0.1 \mu \mathrm{M}$ from the surface to $100 \mathrm{~m}$ depth. In the northern transect, nutrient concentrations tended to be lower than in the southern transect, especially in inshore waters, where the upwelling of deep water was less intense than in the southern transect. In this transect, the highest values of nutrients were observed at the most coastal stations, where phosphate reached $0.54 \mu \mathrm{M}$ and nitrate $0.3 \mu \mathrm{M}$ at the surface $(5 \mathrm{~m})$ of Stn 2. Nutrients decreased towards the most oceanic area, where low values of nitrate, around $0.19 \mu \mathrm{M}$, were found in the water column from the surface to $100 \mathrm{~m}$ depth (C. M. Duarte unpubl. data). These gradients were followed by contrasting differences in phytoplankton chlorophyll a concentrations that varied from $0.05 \mu \mathrm{g} \mathrm{chl} \mathrm{a} \mathrm{l}^{-1}$ in surface waters of the northwestern corner of the study area to a maximum of $4.8 \mu \mathrm{g}$ chl a $\mathrm{l}^{-1}$ in the coastal area of the southern transect.

\section{Abundance}

The pico-phytoplanktonic community was dominated by pico-cyanobacteria of the genera Synechococcus and Prochlorococcus, which were present in the area sampled at respective cell concentrations from $6 \times 10^{2}$ to $9 \times 10^{5}$ cells ml ${ }^{-1}$ and from $1.2 \times 10^{3}$ to $2.3 \times$ $10^{5}$ cells $\mathrm{ml}^{-1}$, indicating that Synechococcus sp. reached a higher maximum abundance than did Prochlorococcus sp.. Maximum pico-phytoplankton abundance was higher for the southern transect (Figs. 4 \& 5). Prochlorococcus sp. was more abundant than Synechococcus sp. for the northern transect, 
where Prochlorococcus sp. showed a maximum cell concentration at the stations located in the middle of the transect (Stns 8 and 14; Fig. 4), with Prochlorococcus sp. abundance decreasing slightly at the coastal and open ocean stations (Fig. 4). Along the southern transect, Prochlorococcus sp. was more abundant at the open ocean stations, decreasing markedly toward the upwelling zone (Fig. 5). Synechococcus sp., however, was more abundant than Prochlorococcus sp. for the southern transect and showed the highest abundance at the intermediate stations, still influenced by the upwelling (Stn 52; Fig. 5). There were also important differences in the vertical distribution of the 2 pico-cyanobacteria, with Prochlorococcus sp. present in deeper waters (from 5 to $200 \mathrm{~m}$ ) than Synechococcus sp. (from 5 to $120 \mathrm{~m}$ ) (Figs. 4 \& 5).

Pico-eukaryotic cells were present in the area sampled, with cell concentrations ranging from $2 \times 10^{2}$ to $6 \times 10^{4}$ cells ml ${ }^{-1}$. The distribution of pico-eukaryotic phytoplankton cells differed from that observed for Synechococcus sp. and Prochlorococcus sp. (Figs. 4 \&
5), showing the highest abundance at the coastal stations, particularly along the southern transect, with their abundance decreasing dramatically below the detection limit in the open ocean areas, especially along the northern transect (Figs. 4 \& 5).

The abundance of phytoplankton cells $>2 \mu \mathrm{m}$ cell diameter (nano- and micro-phytoplankton) varied greatly in the study area. Nano-phytoplanktonic cell abundance was low in oceanic areas and increased strongly at stations influenced by the Canary Current and NW African upwelling, particularly along the southern transect (Fig. 6). The abundance of nanophytoplankton increased at the stations most influenced by the NW African upwelling zone, from 135 to

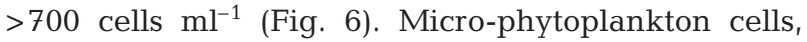
dominated by diatoms, were almost absent at the northern transect, but they were present throughout the southern transect, where micro-phytoplankton abundance varied from 2 to 3887 cells $\mathrm{ml}^{-1}$ from the oceanic waters to the coastal upwelling area (Fig. 6). The maximum abundance of micro-phytoplankton was

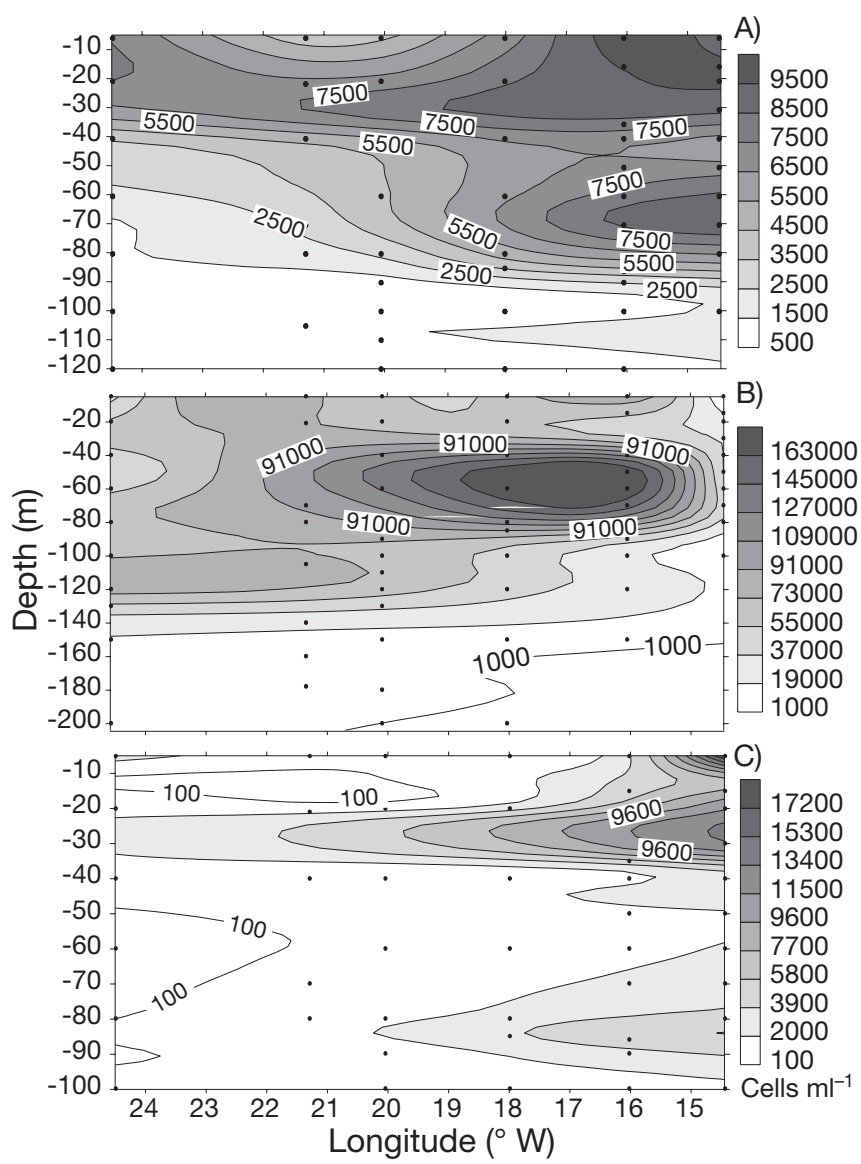

Fig. 4. Cell abundance distribution (cells $\mathrm{ml}^{-1}$ ) of (A) Synechococcus sp., (B) Prochlorococcus sp. and (C) pico-eukaryotic cells across the northern transect. Dots represent the sampling depths

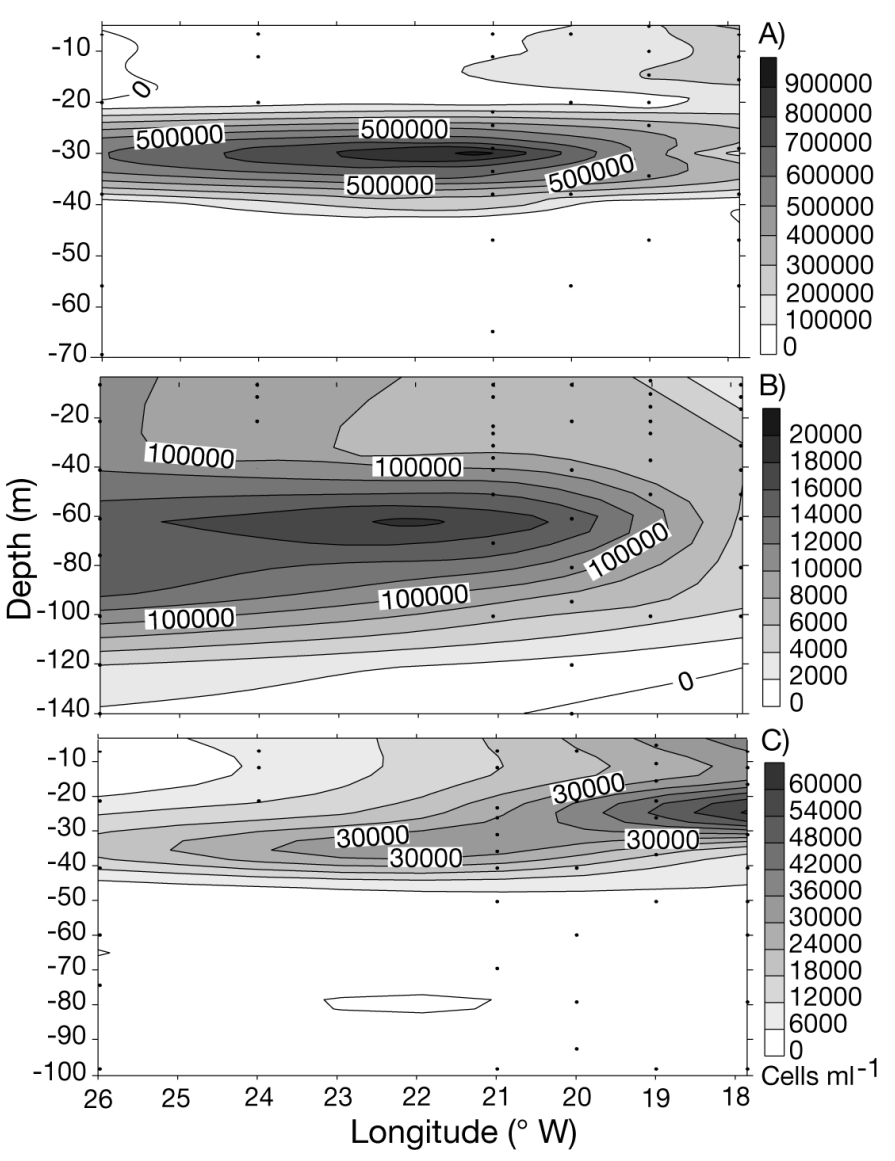

Fig. 5. Cell abundance distribution (cells $\mathrm{ml}^{-1}$ ) of (A) Synechococcus sp., (B) Prochlorococcus sp. and (C) pico-eukaryotic cells across the southern transect. Dots represent the sampling depths 

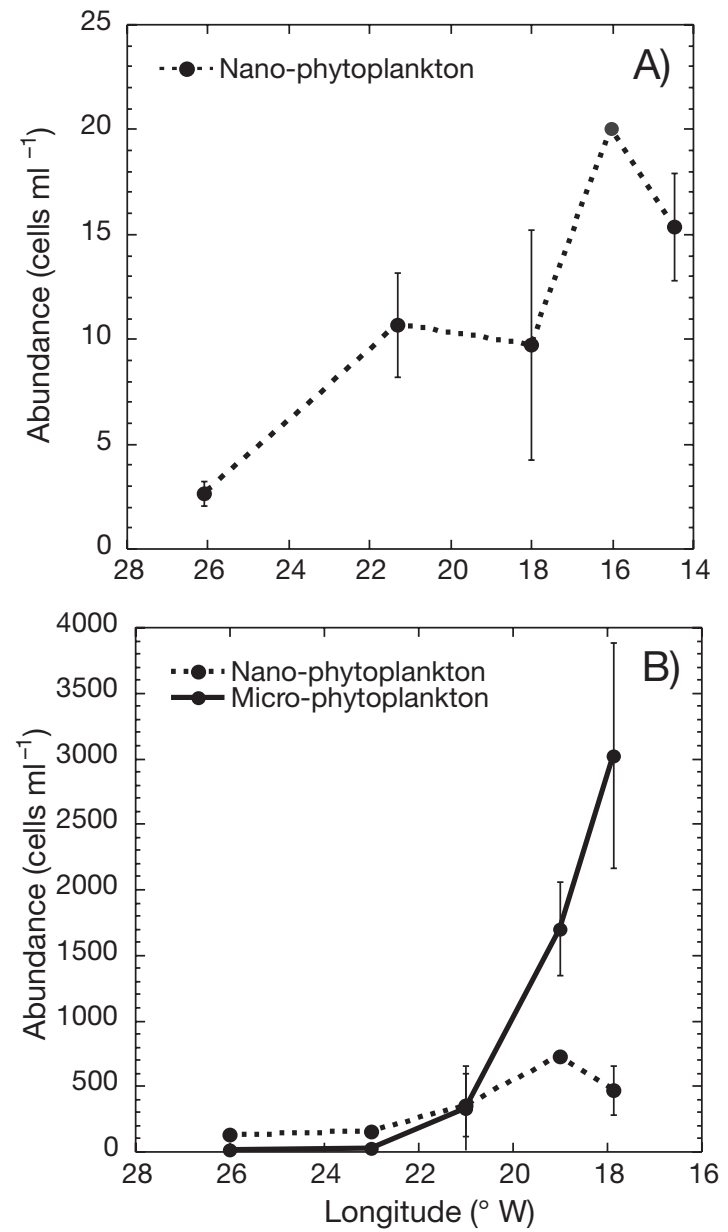

Fig. 6. Depth-averaged $( \pm \mathrm{SE})$ cell concentration $\left(\right.$ cells $\left.\mathrm{ml}^{-1}\right)$ of nano- and micro-phytoplankton at the stations sampled along the (A) northern and (B) southern transects. Dotted and solid lines represent the nano- and micro-phytoplankton abundance, respectively

observed at the coastal stations in the southern transect, indicating an important response of micro-phytoplankton to NW African upwelling (Fig. 6).

\section{Cell viability}

The cell viability within phytoplankton communities varied greatly throughout the study. Synechococcus sp. populations showed a percentage of living cells ranging from 40 to $100 \%$ LC, being generally higher than those observed for Prochlorococcus sp., which varied between 20 and $90 \%$ LC. The quantification of Synechococcus sp. and Prochlorococcus sp. living cells was always difficult; however, when population abundances of these groups were low, as occurred in samples from the surface of the upwelling zone (Stns 60 and 66, for Prochlorococcus sp.) and from the sur- face of the most oligotrophic stations (Stn 32, for Synechococcus sp.), estimates of the percentage of living cells were impossible to compute reliably.

Prochlorococcus sp. showed a vertical pattern of \% LC, especially at the northern transect, characterized by low values of \% LC (between 20 and $40 \%$ LC) at the surface, increasing with depth to reach a maximum of up to $80 \%$ LC in deeper layers. The cell viability of Synechococcus sp. did not show the vertical patterns observed for Prochlorococcus sp. The Prochlorococcus sp. vertical distribution was related to the light environment found in the different areas sampled. The percentages of living cells of Prochlorococcus sp. showed low values, $<60 \% \mathrm{LC}$, in waters where the $\%$ UVR received (relative to surface values) was $>10 \%$ (Fig. 7), with viability increasing, however, at the water depths where UVR was low. Synechococcus sp. \% LC values were not related to underwater UVR, but showed high values at the depths where $>30 \%$ PAR was received (Fig. 8); the viability of Synechococcus sp. decreased, showing values $<60 \%$ LC, in layers where $<30 \%$ PAR was measured.

When averaging at each station the \% LC values from the different depths sampled, Synechococcus viability in the northern transect was higher at the intermediate stations (Fig. 9), with the lowest Synechococcus sp. cell viability found at the coastal stations (Fig. 9). The averaged Prochlorococcus sp. $\%$ LC did not show a clear pattern along the northern transect, varying from $55.5 \pm 9.47$ to $67.5 \pm$ $11.12 \%$ LC. At the stations of the southern transect, the averaged \% LC of both Synechococcus sp. and Prochlorococcus sp. was highest at the most oceanic stations and decreased markedly towards the upwelling zone (Fig. 9). The maximum viability of Prochlorococcus sp. during the study was observed at

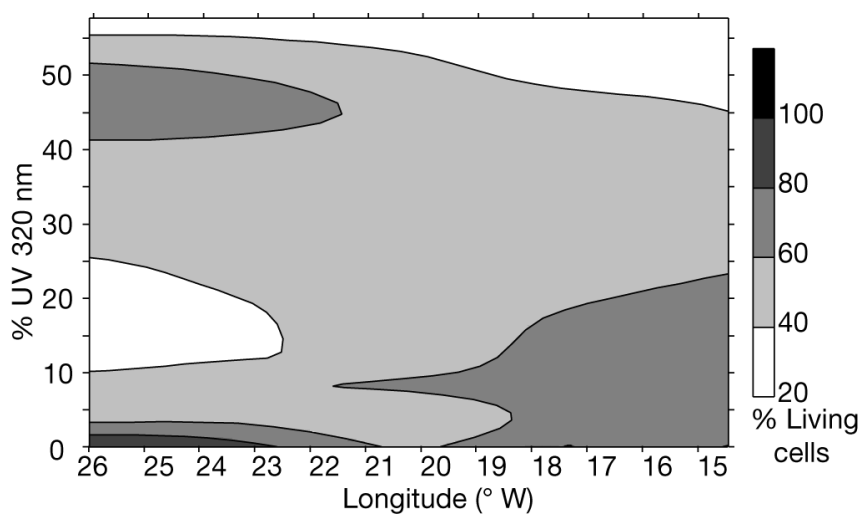

Fig. 7. Prochlorococcus sp. Percentage of living cells with ultraviolet radiation (as \%UVR relative to sub-surface values) throughout the study area 
the oceanic station in the southwestern corner of the study area, where the averaged value was $80.7 \pm$ $7.49 \%$ LC (Fig. 9).

Both Synechococcus sp. and Prochlorococcus sp. cell viability showed a response to the variability of water temperature (Fig. 10). The \% LC of both populations increased with increasing water temperature above $21^{\circ} \mathrm{C}$ (Fig. 10), although the viability of both cyanobacteria showed low values in the areas where temperatures were $<21^{\circ} \mathrm{C}$. The increase in \% LC with increasing temperature was more pronounced for Synechococcus sp. than for Prochlorococcus sp., as indicated by the slopes of the relationships (Fig. 10), which, however, was not significant for Prochlorococcus sp.

The low abundance of pico-eukaryotic cells at most of the stations strongly hindered identification of the population limits of this group in the flow-cytometer plots, and precluded the quantification of the \% LC for these populations in most samples. At the most coastal stations, however, where pico-eukaryotic cells were more abundant, the \% LC observed was high, showing values close to $100 \%$ LC in the upper layers of the water column.

The station-averaged \% LC for nano-phytoplankton varied from the open ocean stations to the coastal waters in both transects, showing low values (mean \pm SE) of $38.7 \pm 6.7$ and $31.1 \pm 6.5 \% \mathrm{LC}$, at the most offshore stations in the northern and southern transects, respectively (Fig. 11), with the cell viability increasing to reach $95.6 \pm 2.9$ and $73.2 \pm 8.5 \% \mathrm{LC}$ at the more coastal stations along the northern and southern transects, respectively (Fig. 11). A similar pattern in the variability of the proportion of living cells was observed for micro-phytoplankton, which were only present in sufficient abundance to assess viability in

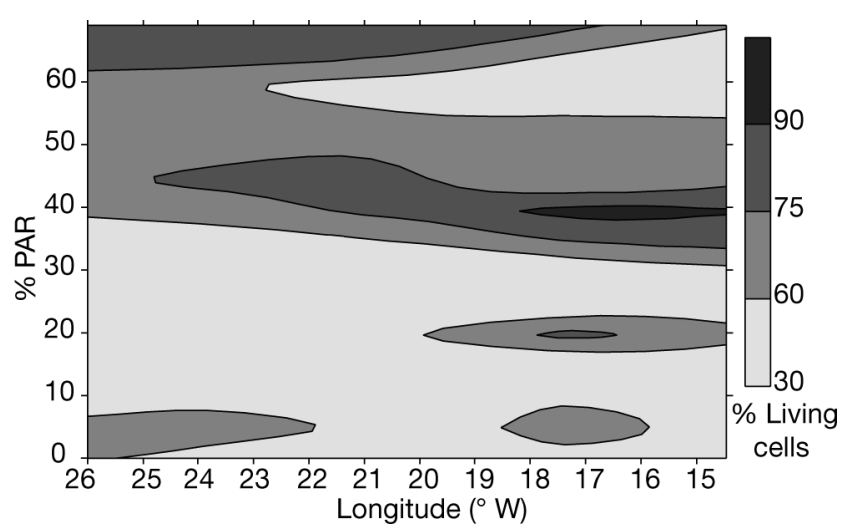

Fig. 8. Synechococcus sp. Percentage of living cells with underwater photosynthetically active radiation environment (as \%PAR relative to subsurface values) throughout the study area
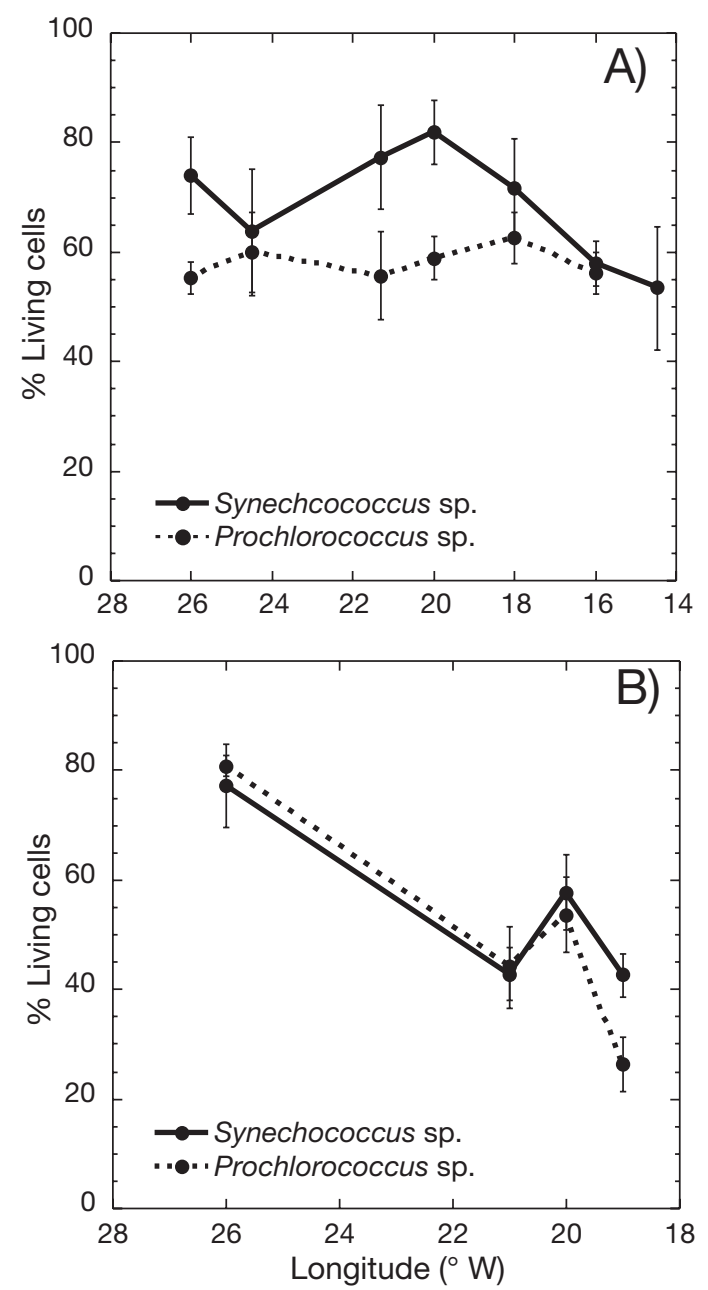

Fig. 9. Distribution of the depth-averaged percentages of living cells of Synechococcus sp. (solid line) and Prochlorococcus sp. (dotted line) in the (A) northern and (B) southern transects. Error bars represent mean $\pm \mathrm{SE}$

the southern transect, with low values of $21.8 \pm 5.5 \%$ LC observed at the most oceanic station and high values of $80.0 \pm 11.5 \%$ LC at the most coastal station in the NW African upwelling zone (Fig. 11). The pattern observed for the variability in the proportion of living cells of both nano- and micro-phytoplankton was in sharp contrast with that for pico-cyanobacteria \% LC, which showed low variation among the stations in the northern transect and decreased from the open ocean stations to the coastal area influenced by the development of NW African upwelling (Fig. 11). Both nano- and micro-phytoplankton cell viability were negatively related to water temperature, with the \% LC decreasing with increasing water temperature (Fig. 10), a pattern that strongly contrasts with that observed for pico-cyanobacteria, which increased viability as water temperature increased (Fig. 10). 

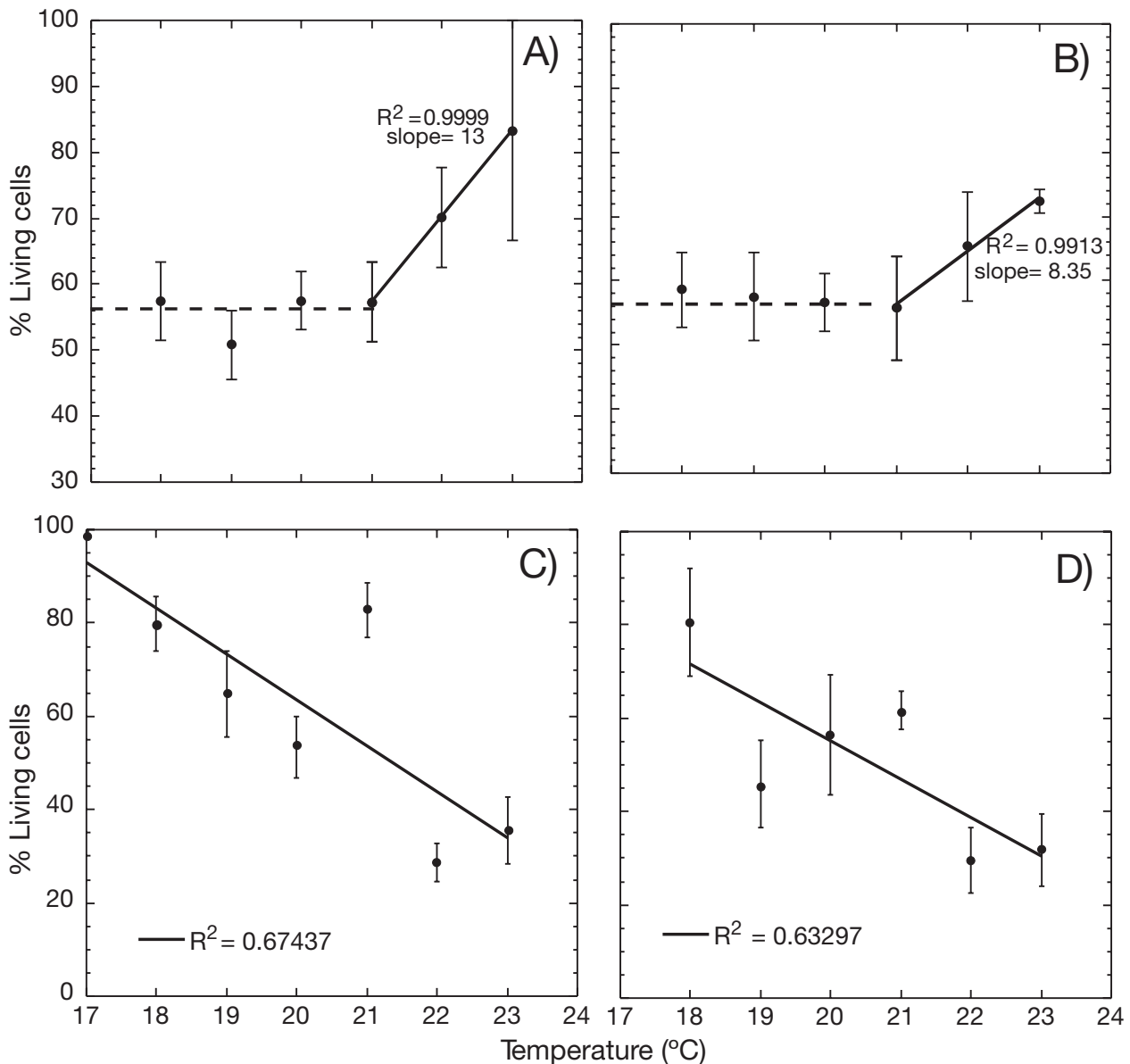

Fig. 10. Relationship between the percentage of living cells, averaged at $1^{\circ} \mathrm{C}$ intervals, and water temperature in the study area, for (A) Synechococcus sp., (B) Prochlorococcus sp., (C) nano-phytoplankton and (D) microphytoplankton. $\mathrm{R}^{2}$ represents the correlation coefficient of the linear regression between the percentage of living cells and temperature. For Synechococcus sp. and Prochlorococcus sp. only the linear regression from 21 to $23^{\circ} \mathrm{C}$ was considered. Error bars represent mean $\pm \mathrm{SE}$

\section{DISCUSSION}

The strong gradients in the environmental conditions that characterize the subtropical NE Atlantic strongly influenced the distribution and viability of the phytoplankton communities studied here. Phytoplankton abundance and community structure strongly changed from the coastal upwelling areas to the open ocean following the changes described in phytoplankton productivity in the area (Margalef 1978, Berger 1987, Hoepffner et al. 1992). Nano- and micro-phytoplankton were more abundant, dominating the phytoplankton communities in the eutrophic upwelled waters, as described previously for the area studied (Margalef 1978, Blasco et al. 1981, Lange et al. 1998). Pico-phytoplankton abundance increased, however as expected, towards the oligotrophic open ocean areas sampled (Olson et al. 1990, Partensky et al. 1996, Zubkov et al. 1998).

The results indicated that the contrasting environmental conditions in the subtropical NE Atlantic, from the eutrophic coastal waters to the oligotrophic open ocean, have also influenced the distribution of phytoplankton cell death. Both nano- and micro-phyto- plankton viability increased from the oligotrophic oceanic stations, where they showed the lowest viability ( 20 to $40 \%$ LC), towards the more eutrophic waters of the African coast, where the percentage of living cells reached 80 to $100 \%$ LC for nano- and microphytoplankton. The increase in viability associated with fertilization by NW African upwelling waters and the coastal upwelling forced northwest by the Canary Current is consistent with studies of phytoplankton cultures that identified nutrient limitation as a factor triggering cell death and reducing the proportion of living phytoplankton cells (e.g. Brussaard et al. 1997, Berges \& Falkowski 1998). A similar increase in microphytoplankton viability related to nutrient availability was described in the Mediterranean littoral for diatoms, which showed low \% LC during the oligotrophic summer period, with the percentage of living cells increasing in the fall, when vertical mixing supplied nutrients to the photic layer (Agustí \& Sánchez 2002). Our results showed that both the abundance and viability of nano- and micro-phytoplankton increased towards coastal waters, indicating that the stress factors causing phytoplankton mortality were reduced in the upwelling areas or that increased nutri- 

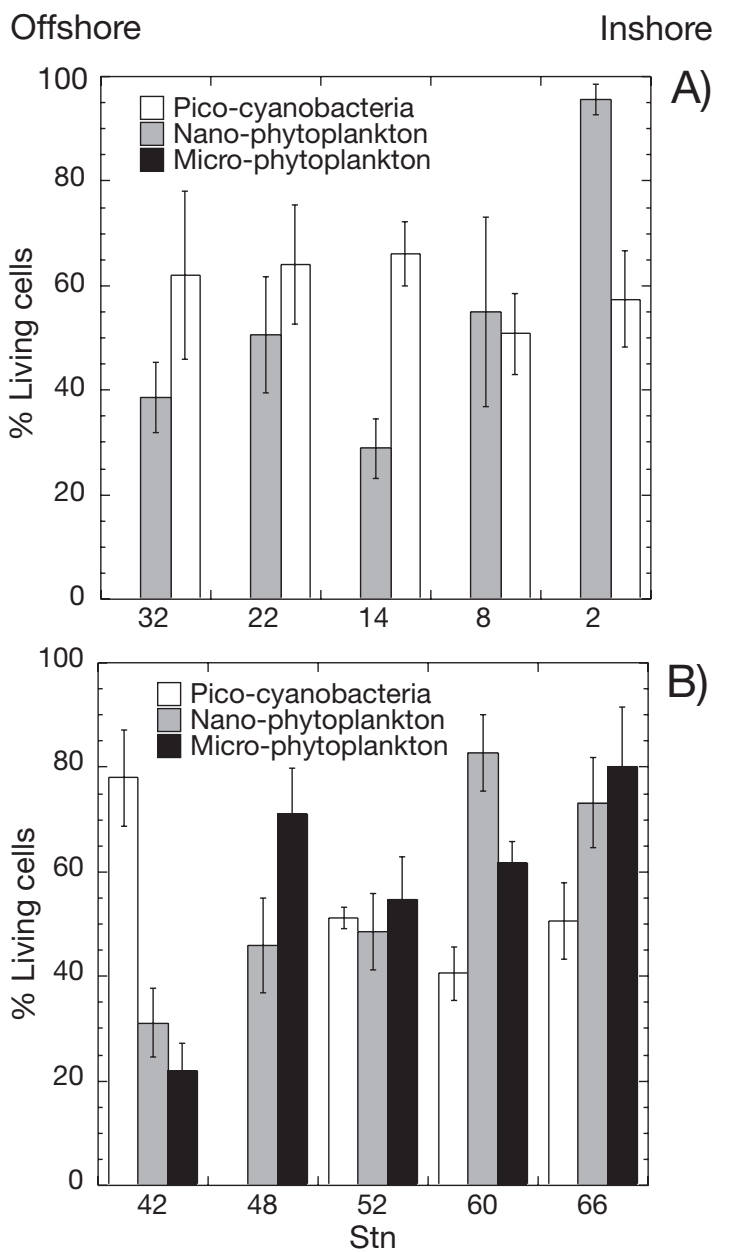

Fig. 11. Distribution of the averaged percentages of living cells for pico-cyanobacteria, nano- and micro-phytoplanktonic communities found in the (A) northern and (B) southern transects, respectively. Error bars represent mean $\pm \mathrm{SE}$

ent inputs reduced the vulnerability to those factors. Maximum nano-phytoplankton abundance was, however, 25 times greater along the southern transect than along the northern transect, reflecting the effects of the increase in cell viability and increased nutrient supply in the southern area.

The tendency observed of an increasing \% LC towards the coast for phytoplankton cells $>2 \mu \mathrm{m}$ is in sharp contrast with the opposite pattern observed for pico-cyanobacteria viability. The \% LC of both Prochlorococcus sp. and Synechococcus sp. decreased from the open ocean to the coastal area of the NW African upwelling zone on the southern transect, although Synechococcus sp. and Prochlorococcus sp. viability remained low at the most oligotrophic stations on the northern transect. The decrease in viability observed here of Prochlorococcus sp. towards the eutrophic area of the upwelling zone is in agreement with evidence concerning the requirement of oligotrophic conditions in culture (Partensky et al. 1999, Scanlan \& West 2002). Prochlorococcus sp. abundance also decreased towards the more coastal eutrophic waters of the upwelling zone, as is in agreement with previous descriptions of the Prochlorococcus sp. distribution in the area (Olson et al. 1990, Partensky et al. 1996). The abundance of Synechococcus sp., however, was more susceptible than that of Prochlorococcus sp. to the upwelling, with the maximum Synechococcus sp. abundance found at the intermediate stations of the southern transect, where it reached the highest picocyanobacteria abundance throughout the study $(9 \times$ $10^{5}$ cells ml $\mathrm{m}^{-1}$ ), with both the abundance and viability of Synechococcus sp. decreasing in the most eutrophic zone of the coast. The response of Synechococcus sp. to increased nutrient availability is in agreement with previous studies reporting stimulation by nitrate inputs (Waterbury et al. 1986, Glover et al. 1988, Agawin et al. 2000).

These results indicate that nutrient supply influenced the viability and distribution of pico-cyanobacteria, but was not the major factor determining the cell death distribution of Synechococcus sp. and Prochlorococcus sp. Our results indicate that water temperature also influenced pico-cyanobacteria cell viability, with both Synechococcus sp. and Prochlorococcus sp. \% LC increasing as water temperature increased above $21^{\circ} \mathrm{C}$, although the increase of Prochlorococcus sp. viability with temperature was not significant. Synechococcus sp. viability exceeded that of ProchlorococCus sp. at the highest temperature range of $23^{\circ} \mathrm{C}(88.3$ $\pm 16.7 \%$ LC, mean $\pm \mathrm{SE}$ ), suggesting that Synechococcus sp. viability may be more sensitive to changes in water temperature. Water temperature is described to be an important factor influencing the growth and distribution of both pico-cyanobacteria, with low temperatures suppressing their growth and strongly influencing their distribution in the ocean (Moore et al. 1995, Agawin et al. 1998, Partensky et al. 1999). In contrast, the viability of both nano- and micro-phytoplankton showed the opposite pattern with temperature, with the \% LC decreasing with increasing water temperature, indicating a possible sensitivity to high temperature values for these groups. High water temperature may negatively affect diatom viability, by increasing the dissolution of their silicon valves (Kamatani 1982).

The viability of Prochlorococcus sp. cells was also strongly influenced by the light environment. The percentage of living Prochlorococcus sp. cells decreased at the surface, where the highest UVR was received, and increased with depth as the UVR decreased. The vertical pattern in the distribution of the \% LC of Prochlorococcus sp. observed here is in agreement with that described by Agustí (2004) for populations in 
the central Atlantic Ocean. The vertical distribution of Prochlorococcus sp. \% LC reflects the high sensitivity to high PAR and UVR of this genus, as demonstrated recently by Llabrés \& Agustí (2006) in experiments with pico-phytoplankton communities from the subtropical NE Atlantic. The vertical distribution of Synechococcus sp. observed here differed from that found for Prochlorococcus sp., with higher values of viability in surface layers and lower values in deeper waters; this is in agreement with the patterns described for central Atlantic Ocean populations and with the high resistance to UVR and PAR found for this genus (Llabrés \& Agustí 2006). Synechococcus sp., however, did not show maximum \% LC values in the waters receiving $25 \% \mathrm{PAR}$, as reported for central Atlantic Synechococcus populations (Agustí 2004).The higher sensitivity of Prochlorococcus sp. compared to Synechococcus sp. to PAR and UVR (Agustí 2004, Llabrés \& Agustí 2006) helps explain the spatial distribution of the 2 pico-cyanobacteria taxa in the area, especially when considering that the underwater irradiance penetration covaried strongly with the trophic conditions of the water bodies in this study.

Synechococcus sp. viability was always higher than that of Prochlorococcus sp., indicating that the conditions found in the area were less stressful for this genus than for Prochlorococcus sp. Agustí (2004) indicated that the contrasting sensitivity to stress factors (high UVR, high and low light, nutrient limitation, etc.), reflected in the different cell death distributions of Prochlorococcus sp. and Synechococcus sp., helps characterize the different niches that the 2 genera occupy across the Atlantic Ocean. In the present study, the differences in the cell death distributions of Prochlorococcus sp. and Synechococcus sp. consistently indicated that there were important differences in the sensitivity to stressors between the 2 picocyanobacteria. Both Prochlorococcus sp. and Synechococcus sp. showed reduced cell death in warm waters, with Prochlorococcus sp. being more sensitive to high light and high nutrient concentrations than Synechococcus sp. As a consequence, the gradient in the environmental conditions of the subtropical NE Atlantic was, in general, more favorable for Synechococcus sp., which was apparently able to cope with a broader range of conditions, than for Prochlorococcus sp. The maximum percentage of living cells of Prochlorococcus sp. was found throughout the water column at the station located in the open ocean area of the southern transect $(80.8 \pm 1.85 \% \mathrm{LC}$, mean $\pm \mathrm{SE})$. This station was, in fact, less oligotrophic than the open ocean stations sampled on the northern transect, but had warmer waters, apparently providing a more favorable environment for Prochlorococcus sp. than the conditions at the other stations. Synechococcus sp., however, showed high viability at this station and at the intermediate stations of the northern transect, indicating a wider range of optimal conditions for this genus within the study area.

The method used to quantify dead phytoplankton cells, the cell digestion assay (Agustí \& Sánchez 2002), requires the incubation of samples at $37^{\circ} \mathrm{C}$. Although the effects of incubation temperature have been described to be negligible for a wide diversity of species (Agustí \& Sánchez 2002, Agustí 2004), the potential effects of high temperature incubation for species that have not yet been tested are uncertain when analyzing natural samples. However, aside from this potential effect, the cell digestion assay is the best method available for the study of natural phytoplankton communities. In comparison to the numerous problems described in the use of vital stains, the enzymatic cell digestion method is free of ambiguity, since cells are either totally digested or remain intact; it does not involve fluorescent signals that may interfere with the natural fluorescence of phytoplankton, and the resulting cell suspensions can be examined under transmitted light microscopy, epifluorescence microscopy and flow cytometry, allowing the analysis of cell viability from the total phytoplankton community (Agustí \& Sánchez 2002).

The \% LC and abundance patterns observed for the various groups suggest that the vulnerability of different phytoplankton taxa to various stressors (e.g. nutrient limitation, low temperature, high UVR and PAR) helps explain their distribution, both vertically and horizontally. Hence, these results point to cell death as a factor structuring phytoplankton communities in the ocean.

As a result of the \% LC distributions of the different phytoplankton communities examined, the highest values of phytoplankton cell death were found at the oligotrophic stations, with the higher proportion of healthy, living cells found in the communities of upwelling coastal waters. This result is in agreement with the measurements of phytoplankton lysis rates reported for the eastern North Atlantic, where low lysis rates were found in the upwelling area although phytoplankton lysis rates increased in the unproductive, oligotrophic zone (Agustí et al. 2001). Consistency between the lowest percentage of living cells in the phytoplankton community and the highest lysis rates for phytoplankton was also reported for the Mediterranean littoral in summer (Agustí \& Sánchez 2002).

In the present study, phytoplankton cell death was detected using a cell-membrane-permeability test (Darzynkiewicz et al. 1994, Agustí \& Sánchez 2002). The increased membrane permeability of dead cells should lead to a high release of cellular compounds into the medium (Myklestad 2000). Hence, the distrib- 
ution of dead phytoplankton cells found in the subtropical NE Atlantic should have consequences for the amount of dissolved organic carbon (DOC) released by phytoplankton. Agustí et al. (2001) found that the carbon sink in the unproductive areas of the eastern tropical North Atlantic was largely supported by a downward flux of DOC that was partially sustained by the excretion of DOC from phytoplankton lysis, which represented up to $70 \%$ of the net primary production in the unproductive area. In addition to its importance in structuring phytoplankton communities, cell death is a major factor affecting the flow of carbon in the region.

In summary, the results presented here indicate that phytoplankton cell dead in the subtropical NE Atlantic was higher in oligotrophic areas and lower in the eutrophic upwelling zone. In addition, important differences were observed in the viability of the different phytoplankton groups forming the communities. The differences found in the distribution of living cells indicated that the factors stressing the pico-sized and larger phytoplankton cells differed strongly and should affect their differential distribution in the subtropical NE Atlantic. The results identified cell death as an important factor structuring phytoplanktonic communities in the ocean.

Acknowledgements. This is a contribution to the project COCA (REN 2000-1474-CO2) funded by the Spanish Ministry of Science and Technology. Patricia Alonso was supported by a fellowship from the Spanish Ministry of Science and Technology. We thank the technical UTM personnel for professional assistance and the BIO 'Hespérides' crew for their professional help during the cruise. We are grateful to E. Alou for sampling and laboratory assistance and to C. M. Duarte for helpful comments on the manuscript.

\section{LITERATURE CITED}

Agawin NSR, Duarte CM, Agustí S (1998) Growth and abundance of Synechococcus sp. in a Mediterranean Bay: seasonality and relationship with temperature. Mar Ecol Prog Ser 170:45-53

Agawin NSR, Duarte CM, Agustí S (2000) Response of Mediterranean Synechococcus growth and loss rates to experimental nutrient inputs. Mar Ecol Prog Ser 206: 97-106

Agustí S (2004) Viability and niche segregation of Prochlorococcus and Synechococcus cells across the Central Atlantic Ocean. Aquat Microb Ecol 36:53-59

Agustí S, Sánchez MC (2002) Cell viability in natural phytoplankton communities quantified by a membrane permeability probe. Limnol Oceanogr 47:818-828

Agustí S, Duarte CM, Vaqué D, Hein M, Gasol JM, Vidal M (2001) Food web structure and elemental (C, N and P) fluxes in the eastern tropical North Atlantic. Deep-Sea Res II 48:2295-2321

Berger WH, Fischer K, Lai C, Wu G (1987) Ocean productivity and organic carbon flux. Part 1. Overviewand maps of primary production and export production. SIO Ref. 87-30,
University of California, San Diego, CA

Berges JA, Falkowski PG (1998) Physiological stress and cell death in marine phytoplankton: induction of proteases in response to nitrogen and light limitation. Limnol Oceanogr 43:129-135

Blasco D, Estrada M, Jones BJ (1981) Short time variability of phytoplankton population in upwelling regions-the example of Northwest Africa. In: Richards FE (ed) Coastal upwelling. Coastal and estuarine science. 1. American Geophysical Union, Washington, DC, p 339-347

Brussaard CPD, Noordeloos AAM, Riegman R (1997) Autolysis kinetics of the marine diatom Ditylum brightwellii (Bacillariophyceae) under nitrogen and phosphorus limitation and starvation. J Phycol 33:980-987

Darzynkiewicz D, Li X, Gong J (1994) Assay of cell viability: discrimination of cells dying by apoptosis. In: Darzynkiewicz Z, Robinson JP, Crissman HA (eds) Methods in cell biology 41. Flow cytometry, Part A, 2nd edn. Academic Press, San Diego, CA, p 16-37

Estrada M, Blasco D (1985) Phytoplankton assemblages in coastal upwelling areas. In: Bas C, Margalef R, Rubíes P (eds) International symposium on the most important upwelling areas off western Africa (Cape Blanco and Benguela). I. Instituto de Investigaciones Pesqueras, Barcelona, p 379-402

Glover HE, Prezelin BB, Campbell L, Wyman M, Garside C (1988) A nitrate dependent Synechococcus bloom in surface Sargasso Sea water. Nature 331:161-163

Grover JP (1990) Resource competition in a variable environment: phytoplankton growing according to Monod's model. Am Nat 136:771-789

Hoepffner N, Baker T, Van Camp L, Nykjaer L, Schlittenhardt P, Murray CN (1992) Marine productivity along the northwest coast of Africa (Mauritania): estimation from satellite data. Proc Central Symp Int Space Year 1:49-54

Huisman J, Weissing FJ (1995) Competition for nutrients and light in a mixed water column: a theoretical analysis. Am Nat 146:536-564

Kamatani A (1982) Dissolution rates of silica from diatoms decomposing at various temperatures. Mar Biol 68:91-96

Lange CB, Romero OE, Wefer G, Gabric AJ (1998) Offshore influence of coastal upwelling of Mauritania, NW Africa as recorded by diatoms in sediment traps at $2195 \mathrm{~m}$ water depth. Deep-Sea Res I 45:985-1013

Llabrés M, Agustí S (2006) Picophytoplankton cell death induced by UV variation: evidence for oceanic Atlantic communities. Limnol Oceanogr 51:21-29

Longhurst A (1996) Ecological geography of the sea. Academic Press, San Diego, CA

Margalef R (1978) Phytoplankton communities in upwelling areas. The example of NW Africa. Oecol Aquat 3:97-132

Marie D, Partensky F, Simon N, Guillou L, Vaulot D (1999) Flow cytometry analysis of marine picoplankton. In: Diamond RA, DeMaggio S (eds) Living colors: protocols in flow cytometry and cell sorting. Springer-Verlag, New York

Moore LR, Goericke R, Chisholm SW (1995) Compartive physiology of Synechococcus and Prochlorococcus: influence of light and temperature on growth, pigments, fluorescence and absorptive properties. Mar Ecol Prog Ser 116:259-275

Moore LR, Post AF, Rocap G, Chisholm SW (2002) Utilization of different nitrogen sources by the marine cyanobacteria Prochlorococcus and Synechococcus. Limnol Oceanogr 47(4):989-996

Myklestad SM (2000) Dissolved organic carbon from phytoplankton. In: Wangersky PJ (eds) Marine chemistry. 
Springer, Berlin, p 111-148

Olson RJ, Chisholm SW, Zettler ER, Altaber MA, Dusenberry JA (1990) Spatial and temporal distribution of prochlorophytes picoplankton in the North Atlantic Ocean. DeepSea Res 37:1033-1051

Partensky F, Blanchot J, Lantoine F, Neveux J, Marie D (1996) Vertical structure of picophytoplankton at different trophic sites of the tropical northeastern Atlantic Ocean. Deep-Sea Res I 43:1191-1213

Partensky F, Hess WR, Vaulot D (1999) Prochlorococcus, a marine photosynthetic prokaryote of global significance. Microbiol Mol Biol Rev 63:106-127

Scanlan DJ, West NJ (2002) Molecular ecology of the marine cyanobacterial genera Prochlorococcus and Synechococcus. Microb Ecol 40:1-12

Van Camp L, Nykjer L, Mittelstaedt E, Schlittenhardt P (1991)

Editorial responsibility: William K. W. Li,

Dartmouth, Nova Scotia, Canada
Upwelling and boundary circulation off Northwest Africa as depicted by infrared and visible satellite observations. Prog Oceanogr 26:357-402

Veldhuis MJW, Kraay GW, Timmermans KR (2001) Cell death in phytoplankton: correlation between changes in membrane permeability, photosynthetic activity, pigmentation and growth. Eur J Phycol 36:167-177

Waterbury JB, Watson SW, Valois FW, Franks DG (1986) Biological and ecological characterization of the marine unicellular cyanobacterium Synechococcus. In: Platt T, Li WK (eds) Photosynthetic picoplankton. Can Bull Fish Aquat Sci 214:71-120

Zubkov MV, Sleigh MA, Tarran GA, Burkill PH, Leakey RJG (1998) Picoplankton community structure on an Atlantic transect from 50 degrees N to 50 degrees S. Deep-Sea Res 45:1339-1355

Submitted: May 17, 2005; Accepted: January 9, 2006 Proofs received from author(s): April 3, 2006 